\title{
Investigating the Influence of Stereotype in Intercultural Communication Towards English Literature Students of Universitas Muslim Indonesia
}

\author{
Andi Hudriati \\ and.hudriati@umi.ac.id \\ Muli Umiaty Noer \\ muliumiatynoer@umi.ac.id \\ Naurah Nadifah \\ naurahfadilah@gmail.com
}

\section{Universitas Muslim Indonesia, Indonesia}

\begin{abstract}
This study's objectives explored two prominent cases: (1) the forms of stereotype in Literature Faculty and (2) how the influence of stereotype in intercultural communication toward the students of Literature Faculty. This study applied qualitative research, which explored the stereotype and intercultural communication toward Literature Faculty students. The researcher applied purposive sampling to gain data. There were 15 students participated as the participant, and the data were obtained through interviews. This study shows that stereotypes in Literature Faculty were stereotypes towards Makassar Ethnicity (Rudely) and stereotypes towards Buginese (Uang Panaik it is too expensive). Even though the students learned many negative stereotypes toward Makassarese and Buginese, most students were not affected by these negative stereotypes. The students chose to trust personal experience and establish effective communication with Makassarese and Buginese, which eventually eliminated negative stereotypes towards the Makassarese and Buginese groups.
\end{abstract}

Keyword: Cultural, Stereotypes, Communication, Student

\section{INTRODUCTION}

Indonesia is a country with a very complex level of diversity. The diversity of tribes and languages in a bond motto Bhinneka Tunggal Ika makes the Indonesian nation a plural island nation. Indonesia has more than 17,000 large and small islands from Sabang to Merauke (D.P.Budi Susetyo, 2010: 1). Bhinneka Tunggal Ika is an Indonesian motto that has been known for a long time. The meaning is different, but still one. The diversity of Indonesian culture is a unique wealth not possessed by every nation globally. The number of tribes that have been known to date is about 300 tribes with customs, habits, and religions different from one another.

Nevertheless, Indonesian's diversity is not without risk. Existing differences are often put as triggers of problems and sources of conflict. Religious, ethnic, and inter-group conflicts often occur. This conflict is often brutal to find a way out because each group feels the most 
correct. The natural conditions of diversity give birth to different styles and influences. An ethnic plurality also gives birth to intra-ethnic groupings because each ethnic group feels superior to other ethnic groups.

Ethnic groups are people who are bound by the awareness and identity of cultural unity. People in one particular ethnic group must have awareness and self-identity towards the ethnic group's culture, for example, in the use of local languages and love the arts and customs. The differences from one ethnic group to another in an area can be seen from the following characteristics - physical types, such as skin color, hair, and others.

Makassar Ethnicity, for example, has a variety of identifications by other ethnic groups. Some assess Makassar people's character tend to be rude, emotional, old-fashioned, and easily angry. Some judge quite polite and honest (Warnaen, 2002: 219-223). Ethnic identity is not only obtained subjectively by defining their own identity. In reality, ethnic identity is sometimes obtained from identification by others outside of ethnicity. Everyday life is known as stereotypes. Embedding negative stereotypes in an ethnic group in some cases becomes a measure to assess the ethnic identity.

The stereotype of a group considers all group members to be the same and have a uniform image. Humans tend never to clarify the stereotyped group's truth but directly accept and follow what is stereotyped. As a result of stereotypes, a person cannot distinguish between the characters possessed by the group members' personalities and the group's characters.

Stereotyping is the attribution of characteristics to a person based on their group membership. Stereotyping has been viewed as inaccurate as it assumes all group members to be similar and ignores the variation between group members. A person may be discriminated against, as it is assumed that they have the stereotypical characteristics of their group. We have to come with an open mind but prepared to suspend disbelief to benefit from the usefulness of non-judgmental cultural generalizations. Encountering another culture and respecting rather than denying is differences from our own culture can be an enriching learning experience. Concerning the above, the problem's objective was (1) to find out the forms of stereotype shown in the Literature Faculty and determine the influence of stereotypes in intercultural communication toward the students.

\section{LITERATURE REVIEW}

Intercultural communication is an exciting object to discuss, so it is not uncommon for many scientific studies to take the realm of intercultural communication as one of the research backgrounds. Research on ethnic stereotypes has been widely studied before; it is just that the context and case studies are different. Some of them are titled: "Stereotip Suku Mandar di Kota Makassar," "Stereotip Suku Minahasa Terhadap Etnis Papua."

Ahmad Rizandy R. (2012) the result of this study showed that the stereotypes that developed against the Mandar in Makassar were almost the same. From the stereotypes in the analysis unit, everything develops and leads to positive stereotypes even though one analysis unit has negative stereotypes towards the Mandar tribe. The analysis units also showed that the factors influence of stereotypes toward the Mandar tribe is the social environment, perception, direct interaction, and cultural elements (beliefs, values, attitudes, and social institutions).

Feybe H Rumondor (2014), in this research, explained that in the lives of the Minahasa and Papuan ethnic communities, there were negative stereotypes and positive stereotypes. In 
general, the Minahasa tribe's stereotypes towards the Papuan Ethnic are very balanced between positive and negative stereotypes. Positive stereotypes that are formed have a sense of unity. There is also a negative stereotype that is difficult to communicate with, drunkards, troublemakers, slow to think, and rude.

If the second research sees two forms of stereotypes that develop in the Minahasa tribal community towards ethnic Papuans. However, here the writer sees how the development of student knowledge of stereotypes and the forms of stereotypes that develop within the Faculty.

The two studies above have very significant differences with the Stereotype Ethnic in Makassar Society. Although using the same theory, but in this study, the variables taken are also very clearly different. This study uses a descriptive qualitative approach with objects of students from different ethnic backgrounds that form a social order on campus, where they have a stereotype of ethnicity.

A stereotype is divided into two types, namely hetero stereotype and auto stereotype. Hetero stereotype refers to stereotypes associated with other groups, while auto stereotypes are stereotypes related to themselves. This stereotype is not always negative but also sometimes contains positive image. This stereotype can be in the form of positive or negative views, usually, it is entirely true, but it can also be entirely wrong (Matsumoto, 2003: 69).

Stereotypes are characteristics imposed upon groups of people because of their race, nationality, and sexual orientation. These characteristics tend to be oversimplifications of the groups involved. While some people truly do embody the traits of their stereotype, they are not necessarily representative of all people within that group. Stereotypes are not always accurate, and even if positive, can be harmful. However, it turns out to be a further influence because stereotypes are not on our behavior, but also the behavior of victims of stereotypes when we interact with those who could be suspected of complacency and thus more damaging. For example members of the group start doing something according to the stereotype and display characteristics that are in accordance with the stereotype. If stereotypes are positive things will certainly be good, but what happens if the embedded stereotypes are negative.

Stereotypes correspond to perceivers' beliefs about the attributes, typically personality traits, that define a group. In line with the idea that intergroup stereotyping follows from, and shapes, the relations between groups and their members, recent research efforts on the so-called Big Two, reveal that two dimensions of stereotyping that are warmth and competence organize the way groups are stereotyped by virtue of their relative status and their interdependence and orient downstream emotions and behaviors. Next to stereotype assessment, we devote special attention to the question of stereotype ambivalence as well as to the compensation effect, two phenomena related to the fact that perceivers tend to see groups either high on warmth and low on competence or vice versa. Another important theme in contemporary work is that interactions are greatly influenced by the fact that people prove sensitive to stereotypical views that they think others hold about them. A final set of issues concern the degree of accuracy of stereotype content in light of their sensitivity to structural and contextual factors impinging on groups as well as the various functions that stereotypes serve (Current Opinion in Psychology, 2016: 90). 


\section{METHOD}

This study's design used descriptive qualitative to know the forms of stereotype and how the influence of stereotypes in intercultural communication. The descriptive method is concerned with the description of data and characteristics about the population. The goal is the acquisition of factual, accurate and systematic data that can be used in averages, frequencies, and similar calculations. The populations of this research are the students of Literature UMI Makassar. The writer took the students of English Literature in 7th semester which consists of 4 classes. A sample is a representative number of a research subject. From 4 classes of English Literature in 7 th semester the authors took 15 students through random sampling technique. Data analysis that is used in this research is descriptive qualitative research and examines the data and all types of information. The data obtained then described in the form of logical and systematic descriptions supported by scientific arguments to answer the problems that exist in this study. The writer analyzed various books of literature and other books or textbooks substance related to study about the problem and topic.

\section{FINDINGS AND DISCUSSIONS}

\section{The forms of stereotype in Literature Faculty}

The writer had analyzed the result of the data collecting of the research. For this part, the writer would analyze the forms of stereotype in the Literature Faculty.

A stereotype is an excessive generalization to someone according to the characteristics that exist in the group (race, ethnicity or religion) or can be called a stereotype is a shortcut in thinking. Stereotypes are not always negative, but if they are influenced by prejudice, they will become negative.

To find out the forms of stereotype, the writer gave several questions about the stereotypes they knew. The stereotype in question is a stereotype that they know does not mean they believe, but rather experiences they have had directly or indirectly.

The result of interview about the forms of stereotype in Literature Faculty described below:

a. Stereotypes towards Makassar Ethnicity

Makassar formerly known as Ujung Pandang is the capital of South Sulawesi. In fact 1946 Makassar was once the capital of the state of Eastern Indonesia.

Makassar with a city inhabited by the majority of the Bugis Makassar tribe still adheres to the philosophy of Siri Na Pacce which is the reference for the lives of the Makassar people itself. Where Makassar people uphold self-esteem and empathy for the fate of others and this philosophy will continue to be under wherever they go.

But on the other hand there are still some people who think that Makassar abbreviation for "Makassar Kasar". Where Makassar people have bad temper, rude and identical with criminal. As some students said:

Extract 1:

"Dulu saya memiliki sebuah stereotip yang menganggap bahwa orang Suku Bugis Makassar (Mangkasa') berkarakter keras, kasar, tidak bisa dipercaya dan pandangan negatif lainnya." 
"I used to think that people in bugis Makassar tribe had a mean character, rude, untrustworthy, and another negative perception."

(Interview with S1)

\section{Extract 2:}

"Dulu waktu sebelum tinggal di Makassar itu dipikiranku rata rata itu tukang doti. Selain tukang doti mereka juga rata rata bicaranya kasar. Terus ada juga lagi pendapatku yang lain itu kayak satu kali ko injak Makassar kau nda bakalan pulang kekampungmu kayak gitu. Jadi menurutku dulu itu bukan dulu sih bahkan sampai sekarang juga punyaka pemikiran pemikiran kayak gitu."

"Once before living in Makassar, I was wondering that most of Makassareses are tukang doti. Beside that, mostly they speak rudely. Another perception of me about Makassar is, once you step Makassar, you could never go back to your hometown. Even at this moment I still have that kind of stereotype in my mind."

(Interview with S2)

A similar experience is also experienced by student 3 :

\section{Extract 3:}

"Dulu itu kan saya orang Sulawesi ja asli tapi dikampung, lahir dan besar dikampung. Pas kuliah baruka injak Makassar. Sebelumka ke Makassar itu yang dikepalaku itu bilangka, aduh bagaimana kalau di Makassar ka ini, jangan sampai berubahka atau jangan sampai makin kan dipikiranku orang Makassar itu hedonki, anak gaul terus kasar. Yang paling kutau itu bilang banyak begalnya, banyak kejahatannya dan berita berita yang kudapat banyak pembunuhan dan lain lain sebagainya. Pas ka sampai Makassar, takut sekalika begitue, mau keluar saja takut, mau ini takut, mau itu takut padahal adaji motorku itu hari tapi selaluka takut karena dikepalaku bilangka jahatki orang Makassar."

"I was born as a native (buginese). I came to Makassar when I was graduated from senior high school to continue my bachelor degree. Before living in Makassar, I felt worry about myself. "will I change (to a negative person)?" because I think that Makassar is a big city with very large society. I was thinking that Makassar is full of hedonists and rude people. All I knew about Makassar was there are so many hijacking cases, crime, and any negative opinion which I found from the news. Right after arriving in Makassar, I felt afraid of going out somewhere although I have motorcycle, it is because my negative stigma about Makassar itself."

(Interview with S3)

The result of interview above show that stereotypes have become prejudices, that is believing something that is not proven and that prejudice has become discriminatory behavior.

b. Stereotypes towards Buginese

The Buginese has a unique culture that still exists today, one of which is "Paniak". "Paniak" is also called "Uang Panai". The tradition is carried out when they want to carry out the process of marriage. 
"Uang Panai" is a dowry given by a man if he wants to propose to his ideal girl. Since long ago now this tradition is still used. "Uang Panai" has a class with the strata of the girl, royal bloodline, profession, beauty and education. Some students argue:

Extract 4:

"Saya sebagai orang Tolaki asli. Melihat banyaknya orang dengan suku Bugis berdagang di wilayah saya. Sehingga kami orang Tolaki berpendapat kalau orang Bugis itu adalah pedagang."

"I am as real tolaki see much buginese people trading in my region. So we argue that Buginese people is a trading."

(Interview with S4)

\section{Extract 5:}

"Sejauh ini toh kalau anggapanku tentang sisi negatifnya Bugis Soppeng ada 2. Yang pertama itu ada istilah kalau di Bugis dia itu bilang mereka bisa membunuh tanpa menyentuh. Terus yang kedua itu masalah uang panai. Kenapa saya nominasikan uang panai sebagai sisi negatif karna menurutku toh contohnya begini, ada orang dari luar Suku Bugis mau pergi melamar anak dara di Bugis tapi karena anggapannya tentang standar uang panainya itu orang Bugis mahalki jadi dia kayak merasa ragui atau kayak tertahanki langkahnya untuk pergi."

"As far as I know there are 2 negative sides about Soppeng Buginese. First, there is a term that saying "they can kill someone without psychical touching. Second, it is about uang panai'. Why do I put uang panai' as negative side because I think that non-buginese men will feel doubt to propose ana' dara because the terrifying stigma about uang panai'- it is too expensive."

(Interview with S5)

Extract 6:

"Contoh dalam Etnis Bugis yang terkenal dengan budaya Panai yang mahal. Kemudian ada beberapa etnis luar Sulawesi tidak mengenal Panai. Mereka berfikir bahwa menikah dengan gadis Bugis sama dengan membeli mereka sesuai dengan tingkat pendidikan atau hal yang di unggulkan dari si gadis. Faktanya uang panai bukan uang mahar. Melainkan uang belanja yang diserahkan kepada keluarga mempelai wanita dan menjadi tanggung jawab awal pria untuk menafkahi calon istrinya melalui Panai yang digunakan sebagai biaya penyelanggaraan acara."

"Examples of Buginese are well-known for their "Panai" culture. Then there are a number of ethnic groups outside Sulawesi who do not know "Panai". They think that marry a Buginese girl is the same as buying them according to their level of education. The fact is that "uang panai" is not dowry. But spending money which is handed over to the bride's family and is the responsibility of the man to support his future wife through "panai" which is used as the cost of organizing the event." 
The same opinion, the student 7 said:

\section{Extract 7:}

"Saya mengatahui tentang stereotip budaya Suku Bugis dimana orang orang mengatakan bila ingin menikahi gadis Bugis harus menyiapkan uang yang banyak karena ada satu tradisi yang dinamakan Uang Panai. Dimana laki laki yang ingin menikah harus menyediakan uang panai yang mencapai ratusan juta rupiah bila tidak memiliki uang sebanyak itu maka jangan harap bisa menikahi gadis Bugis. Menurut saya tidak semua anak perempuan dan keluarga perempuan Bugis masuk dalam tradisi ini. Sudah banyak perempuan Bugis yang menikah tanpa memberikan beban berat untuk Si laki laki yaitu uang panai yang besar."

"I know the stereotype about buginese where people said if we want to get marry to a girl, we have to prepare amount of money. It is due to "uang panai" where the man who want to married must prepare uang panai around billion rupiah and when your money is not enough then do not except you can marry buginese girl."

(Interview with S7)

The result of interview above show that the students claimed to hear negative stereotypes toward Bugis Ethnicity, but they chose not to believe immediately.

\section{The influence of stereotype in intercultural communication toward the student of Literature Faculty}

The writer had analyzed the result of the data collecting of the research. For this part, the writer would analyze how the influence of stereotype in intercultural communication toward the students of Literature Faculty.

Stereotype is one of several factors that can hamper intercultural communication. Because these stereotypes can make us draw conclusions too quickly about someone without knowing the individual's character.

In this study, the intensity of communication toward students has a positive influence on cognitive, affective and behavioral aspects. It means that the process and results of student social learning can ward off existing negative stereotypes. From the interview analysis, most students get a positive impression and feel comfortable while communicating and do not justify the circulating stereotypes.

The result of interview about the influence of stereotype in intercultural communication toward the students of Literature Faculty described below:

Extract 1:

Saya menjalin hubungan yang sangat baik dengan teman yang notabene berlatar belakang Suku Bugis Makassar asli. Mereka baik namun memiliki sisi kekurangan sebagaimana manusia pada umumnya. Sejauh ini yang saya pahami dari teman saya, mereka setia kawan, ramah dan ceria juga jenaka.

(Interview with S1) 
I have a good relationship with my friend with bugis Makassar background. They are kind despite they have a negative side like people in common. As far as I know from my friend, they are loyal, friendly, and humorist.

The extract above show that the student claimed to have a fairly high communication intensity and had a fairly close emotional relationship with the Makassar Ethnicity as a friends.

\section{Extract 2:}

Kalau hubungan sampai sekarang itu baik baik ji. Maksudku malah nyamanka sama orang orang disini (Makassar) cuman misalnya ketemuka sama orang orang baru atau ketemuka sama orang orang yang sudah kugaris bawahi, prasangka prasangka ku itu yang kayak gampang ini ma'doti ini orang karena cantik semua ceweknya. Terus kalau misalnya juga bicarai toh cepat sekali bicaranya baru terkesan kasar ki otomatis sudah kugaris bawahi kalau mereka ini orangnya kasar padahal nda ji kayak begitu.

(Interview with S2)

For now I feel comfortable with my new environment. But when I meet a new individual, my negative stereotype (as I said before) is coming. Furthermore, sometimes I feel intimidated with the way they are talking. They talk as they are yelling at me while I know that they don't mean it, it is because their way to speak is just like that.

\section{Extract 3:}

Dulu, kan sekarang pindah kos ka, 2 tahun yang lalu pindah kos ka di Alla' Alla'. Nah ini Alla' Alla' kalau di Abdesir paling terkenal paling banyak begalnya. Sebelumka kesini siap ja ambil resiko karena bilangka mauka cari tempat yang agak sepi dan mau ja kurasa berbaur sama orang Makassar. Nah sampai disini Alla' Alla', sebenarnya agak takutja dan selaluka berpandangan buruk terhadap ibu ibu yang disitu. Difikiranku toh bilang jangan sampai ini ibu ibu yang ajarki anaknya begini, jangan sampai ini ibu ibu ini yang begini yang negatif apa begitu. Lama lama ternyata baik hubunganku sama mereka. Akrab ka, seringka dibantu, anak anak lorong yang kukira tukang begal ternyata orang berpendidikan ji, cuman mereka penampilannya kalau kayak merasaki dikampung kan nda hedon meki, nda kayak anak di kota, nda kayak anak anak yang tinggal di perumahan perumahan, pasti mereka juga jaga image ki dari pakaian dan lain lain. Nah kalau anak di lorong kan nda begitu dan ternyata yang kukiranya mereka anak lorong, anak berandalan, anak busur, anak tukang begal ternyata bukan. Mereka anak anak sekolahan ji cuman begitu tinggal di lorong. Tingkat perekonomiannya ji yang membedakan tapi dari pendidikan samaji.

(Interview with S3)

I had lived in Alla'-alla' for two years, as what already sticked to my head is, this area is dangerous because most of hijacking cases happened there (particularly in Abdesir). Before coming out here, I was ready to take all the risks because I was looking for a new environment and I want to mingle with them (Makassarese). At the first time I always thought negatively even for moms 
in Alla'-Alla'. I was wondering they taught their children to become bad guys. But as the time flew I get closer to them and they always gave me hands whenever I needed help. The youths which I considered as bad guys are actually educated too. It is just their appearance to dress like that because they feel that they are not living anywhere but home so they just keep being the way they are. The only distinction is the economic status, but in educational background, they are equal with another society out there.

The extract above shows that the students have a fairly good personal relationship with the Makassar Ethnicity having a high intensity of communication and positive social learning toward the Makassar Ethnicity by conducting a direct social learning process.

Extract 4:

Hubungannya baik baik saja dengan hadirnya mereka dikampung kami sehingga meningkatkan daya saing dalam hal budaya dan pereekonomian.

(Interview with S4)

I have good relation, therefore their presence can improve our competitiveness in culture and economic side.

\section{Extract 5:}

Hubunganku dengan suku Bugis Soppeng bisa dibilang baik baik saja atau normal ji karna maksudnya tetap ja mampu untuk hidup berdampingan tentang anggapannya orang mengenai Suku Bugis baik itu anggapan negatifnya ataupun positifnya tanpa haruska permasalahkanki anggapannya itu orang tentang Suku Bugis Soppeng.

(Interview with S5)

I have a good relationship with soppeng buginese because I can still put myself in the circumstances without having any trouble.

Extract 6:

Saya cenderung berusaha melihat satu masalah dari sudut pandang berbeda. Perlu mendengar penjelasan dari satu kelompok. Sebelum mereka menjustifikasi kelompok lain. Setiap kelompok punya pendapat dan alasan masing masing.

(Interview with S6)

I tend to try to see a problem from a different perspective. Need to hear an explanation from one group. Before they justify other groups. Each group has their own opinions and reasons.

In extract 4-6 shows that the students have a pretty good relationship even though they don't have a close personal relationship with the Bugis Ethnicity.

Extract 7:

Hubungan saya dengan kelompok etnis ini cukup baik karena bisa dibilang saya tergolong dalam kelompok ini cuma saya tidak mengikuti tradisi seperti mereka. 
My relation with buginese is good enough because I am one of them but I do not follow their tradition

The extract above show that the student not only have experience of hearing or understanding stereotypes of the Bugis Ethnicity but also become victims of negative stereotypes because students belong to the Bugis Ethnicity.

The results of interview show that the stereotypes circulating in the Literature Faculty had no impact on students. Some students claimed not to believe in stereotypes because they have personal experiences that break those stereotypes. The process of social learning obtained from others will be broken by the process of direct social learning. Therefore direct interaction can increase understanding between groups so that negative stereotypes and discriminations do not arise. The Literature Faculty is an example of student social learning that has positive results. The process of social learning in the Literature Faculty brings students in a diverse and harmonious life.

\section{Discussion}

In this part, deals with the interpretation of the findings based on the result of descriptive analysis and the data gained from the interview in order to give detail information.

The present study aimed to assess the role of stereotype and intercultural communication toward the students of Literature Faculty. In addition there are two questions were explored: what the forms of stereotype in Literature Faculty and how the influence of stereotype in intercultural communication toward the students of Literature Faculty. A group of students with different ethnicity background participated in this study. The researcher had an interview to explore the role of stereotype and intercultural communication toward the students of Literature Faculty. The main finding was that there were negative stereotypes in Literature Faculty. Meanwhile the influence of stereotype in intercultural communication had no impact on students of Literature Faculty.

The analysis of data presentation from problem statement addressed discussed in this part. The discussion divided into two parts based on the problem statement; the forms of stereotype in Literature Faculty and how the influence of stereotype in intercultural communication toward the students of Literature Faculty.

\section{The forms of stereotype in Literature Faculty}

There were 2 forms of stereotype in Literature Faculty found in the interview:

a. Stereotypes towards Makassar Ethnicity (Makassar Kasar)

Many people consider the word Makassar to contain the word "Kasar" so that some people interpret Makassar as an abbreviation of "Makassar Kasar", even though this is not the case. The word Makassar itself consists of two words. "Mang" which means it has properties or is contained therein. Then the word "Kasarak" which means visible, bright and clearly visible. So the combination of these two words forms the word "Mangkasarak" which later in Indonesian is "Makassar" which means to have a clear and open nature or have a clear character.

The second reason of the Makassar people are considered rude is because of the way of Makassar people to speak. Their way to speak can be considered to be harsh and sometimes 
rather loud. But harsh does not mean rude. And usually Makassar people speak directly on the subject. No wordy and don't like pleasantries.

And the third reason is the media. There was a lot of media coverage regarding the riots, criminal acts and student brawls in Makassar so that the Makassar people were known to be rude. That is the assumption that attached and embedded as the character of Makassar people itself.

\section{b. Stereotypes towards Buginese (Uang Panai)}

The culture of marriage in each region has always been a very interesting thing to discuss. Both in terms of the cultural background of the marriage and in terms of the complexity of the marriage itself. Because in a marriage that occurs not only unites two people who love each other, more than that, there are values that can not be separated to be considered in marriage such as social status, economic, and cultural values of each family of men and women.

In South Sulawesi, in the culture of Bugisnese marriage itself there is one thing that seems to have become distinctive in a marriage to be held, it is due to "Panai" or by the local people called "Uang Panai". "Uang Panai" is the amount of money given by the prospective bridegroom to the bride and groom who will be used for the purposes of holding a wedding and other wedding shopping. "Uang Panai" is not counted as marriage dowry but as customary money but is considered mandatory with the amount agreed upon by both families.

"Panai" is famous for its large nominal amount. The amount is determined by several factors. (1) Women's membership in a family. For example the woman's family has a high social status in the environment. (2) Having a physical condition that is considered perfect. The more perfect the physical condition, the higher the amount is pegged. Even the woman does not have a good social status, not from the aristocratic class, does not have a high level of education, her physical condition will be a measure of the amount of "Uang Panai". (3) High educational status. For example, having a job and high education. (4) Has a high amount of material wealth among residents in the surrounding environment. (5) Brides have a high level of power and strength. For example, the woman has great authority in an organization so that it makes her status higher than other members of the organization.

\section{How the influence of stereotype in intercultural communication toward the student of Literature Faculty}

We are often unconsciously equate someone with another person because they come from the same group or culture. This is done on the basis of our perception of a group that is rooted continuously. There are positive stereotypes and negative stereotypes. The definition of stereotype is to generalize people based on little information and form people's assumptions based on their membership in a group.

It can also be defined as an assessment of someone based on the perception of the group in which the person can be categorized. In other words, stereotyping is the process of placing people into categories, or judgments about people or objects based on appropriate categories rather than based on their individual characteristics.

Stereotype is one of several factors that can inhibit cultural communication. Because these stereotypes can make us draw conclusions too quickly about someone without knowing the person's individual character. For example, many people think that Makassar people had a mean character, rude, untrustworthy, and another negative perception. This is one example of negative stereotypes that people give to Makassar people. Another example, Buginese people 
who are famous for their culture "Panai" where the man who want to married must prepare "uang panai" around billion rupiah and when your money is not enough then do not expect you can marry Buginese girl.

Based on some examples above, it can give an idea that humans in valuing others, especially those who are not part of or outside the community, realize or not often trapped in stereotypes and cultural overgeneralization. Here are some tribal images that often lead to misunderstanding in communication.

This is what often makes us trapped in stereotypes and overgeneralization of culture, which often inhibits of cultural communication and even at risk of cultural offense. In other words, the assessment is often only by using glasses of our own cultural or behavioral, to measure and evaluate the culture and behavior of others.

\section{CONCLUSIONS}

The conclusions of this research were presented based on the data which have been analyzed in the previous chapter. From all the data analysis about the forms of stereotype in Literature Faculty and how the influence of stereotype in intercultural communication toward the students of Literature Faculty. It can be concluded that there are two forms of stereotype in Literature Faculty. The first is stereotypes towards Makassar Ethnicity. The second is stereotypes towards Buginese. And that the influences of stereotype in intercultural communication toward the students of Literature Faculty had no impact on students. The Literature Faculty is an example of student social learning that has positive results. The process of social learning in the Literature Faculty brings students in a diverse and harmonious life.

\section{REFERENCES}

D.P. Budisusetyo. 2010. Stereotip dan Relasi AntarKelompok. Yogjakarta: Graha Ilmu.

Effendy, Onong Uchjana. 2003. Ilmu Teori dan Filsafat Komunikasi. Bandung: PT. Citra AdityaBakti.

Hudriati, A., Ratnawati, R., \& Riskawati, R. (2017). Analysis of Culture Shock Experienced by The New Students of English Department In Faculty of Letters UMI Makassar. Tamaddun, 16(1), 21-29.

Mufid, Muhammad. 2005. Komunikasi Dan Regulasi Penyiaran. Jakarta: Kencana Prenada Media Group.

Mulyana, Dedi. 2014. Komunikasi Antarbudaya Panduan Berkomunikasi Dengan OrangOrang Berbeda Budaya. Bandung: PT. Remaja Rosdakarya.

Priandono, Tito Edy. 2016. Komunikasi Keberagaman. Bandung: Remaja Rosdakarya.

R. Ahmad Rizandy. 2012. Skripsi "Stereotip Suku Mandar di kota Makassar, Studi Komunikasi Antarbudaya Suku Bugis dan Suku Mandar”. Makassar: Fakultas Ilmu Sosial Ilmu Politik Universitas Hasanuddin.

Rivai, Veithzal dan Deddy Mulyana. 2012. Kepemimpinan dan Perilaku Organiusasi. Jakarta: PT. Raja GrafindoPersada.

Rumondor, Feybe H. 2014. "Stereotip Suku Minahasa Terhadap Etnis Papua". Journal Acta Diurna Vol, III. No.2. Accesed on April 2020, 19:36. 
Shoelhi, Mohammad. 2015. Komunikasi Lintas Budaya Dalam Dinamika Komunikasi Internasional. Bandung: Simbiosa Rekatama Media.

Umiaty, Muli, dkk. 2018. Cross Culture Understanding : Multicultural Education Based Instruction For Conflict Resolution. Yogyakarta: Phoenix Publisher.

Warnaen, Suwarsih. 2002. Stereotip Etnis dalam Masyarakat Multietnis. Yogyakarta: MATABANGSA. 